\title{
Slovenes and Friuli as the Other in Hemingway
}

\author{
Rebecca Johnston
}

\section{ABSTRACT}

Ernest Hemingway was known for writing with the "Iceberg Theory" in mind. Thus, there are deeper meanings and contexts moving beneath the surface of his works. His war novel A Farewell to Arms takes place along the Soča/Isonzo Front both before and after the Battle of Kobarid/Caporetto and in this setting, consistent with his "Iceberg Theory," Hemingway has placed both characters and settings that deserve a reconsideration below the surface. While the Italians in the novel are on the surface of the story and thus more easily recognizable, it is the Slovenes and Friuli who run under the surface and carry a deeper meaning. Slovenes and Friuli are not named directly, but as Hemingway was historically accurate in the novel, both ethnic groups are placed along the Front and collectively they represent the "other" in Hemingway's novels, both unseen and integral to the storyline.

Keywords: World War One, Isonzo Front, Soča Front, Hemingway, A Farewell to Arms, Slovenes, Friuli, Italian Front, Caporetto, Kobarid, Nick Adams 
In WWI, Italy invaded the Slovene portion of the Austro-Hungarian Empire. Thus, when Lt Henry was injured north of Plava, he was injured while assisting the Italian army in an occupied Slovene town. According to Gregor Kranjc, "Hemingway never acknowledged, with the exception of a few obscure references to Slovene place names like Lom or Ravne, that the battles were taking place in territory that was largely populated by Slovenes" (209). In fact, he consistently used the Italian names for every other location in the published version of the novel. However, Hemingway placed Slovenes below the surface of his writing. In addition, a second group, the Friuli, also exists below the surface. Slovenes and Friuli are "the other" in Hemingway's WWI writing; they are both unmentioned and integral to the story.

Lt Henry and Nick Adams were supporting Italy during irredentism (FTA 19). Just as Hemingway "made every attempt to integrate himself to the foreign culture" so did his characters ( Ammary 3). Lt Henry is mostly "embraced by Italians" (Ammary 3). Ammary comments that "Frederic Henry's close friendship with Rinaldi and the priest exemplifies the sense of brotherhood that has developed between the American Henry and the Italian officers" (14). This immersion into Italian culture is likely connected to Hemingway's own disconnection from the cultures that were hidden beneath Italian culture. Italians and Slovenes have a history of struggle between them. The Italians sought to gain Slovene towns in WWI, and they took Slovene land after the war. Mark Thompson mentions a moment when Mussolini passed over the old border into ethnically Slovene land and asked the name of a young boy. The boy had the Slovene sounding name of Stanko. Mussolini asks his last name and Thompson states that Mussolini "does not realize that Stanko must be a Slovene" (144). When he is told the Slavic last name of "Robančič, Mussolini "changes the subject" (Thompson 144). Similar to this brief conversation, Mussolini would attempt to bury the Slovene culture and way of life. Given the influence of Italians on Hemingway, it is not surprising that Slovenes do not have a clearer role in his WWI writing. As Branko Drekonja states, "Inevitably...[Hemingway was ] a victim of Italian irredentism" (19). However, Hemingway does include Slovenes below the surface, which gives their suffering importance in his works.

One of the ways Hemingway places Slovenes in his writing is when he hints that the Italians are fighting in a foreign land. Lt Henry is speaking with his fellow ambulance drivers when one of the men states "What if we take San Gabriele?... If...[the Austrians] come down into Italy they will get tired and go away. They have their own country" (44). The comment "what if we take San Gabriele" shows that they knew the land was not under Italian control. It would be taken, not taken back-just taken. These men realize they are invading a country. The mountain they are speaking of is Škabrijel, a mountain that belonged to the Austro- 
Hungarian Empire within Slovene territory. While these men realized they were invaders, some of the Italians fighting with Lt Henry were not aware. Italian irredentism led the people to believe that they were redeeming land that belonged to Italy. When discussing the war and the difficulties of strategizing for a war in the mountains, Gino said, '“Yes,'...'But those were Frenchmen and you can work out military problems clearly when you are fighting in somebody else's country.' 'Yes,' I agreed, 'When it is your own country you cannot use it so scientifically"' (160). This discussion takes place before the Battle of Caporetto in a town on the Bainsizza Plateau, which the Italians had taken from the Slovene portion of the Austro-Hungarian Empire. Yet, Gino and Lt Henry come to the conclusion that this war is hard to discuss scientifically because the fighting takes place in Italy. There are several similar examples, such as when Lt Henry states that, "The town [of Gorizia] had been captured very handsomely but the mountains beyond it could not be taken," these mountains would have been in Slovenia (5). When Lt Henry is questioned alongside the Tagliamento during the retreat, he is told "it is you and such as you that have let the Barbarians onto the sacred soil of the fatherland" (FTA 193). However, much of the land was not Italian to begin with. Perhaps in this contradiction Hemingway is showing the contradiction within Italy during the war. So many Italians felt that they were fighting for unredeemed Italian lands, but the obvious fact that they were outside of Italian lines fighting for a country not occupied by Italians was clear. Not all Italians realized it, but soldiers on the front lines were beginning to figure it out, and Hemingway quietly pointed to this invaded group of Slovenes.

Invaded people groups are further seen in FTA. Lt Henry states, "In the late summer of that year we lived in a house in a village that looked across the river and the plain to the mountains" (FTA 3). This house was not built by the Italian military. Reynolds puts this house in either Gradisca or Lucinico, both of which were in the Slovene portion of the AH empire (91). The following summer, Lt Henry is stationed across the river from Lucinico in " a house in Gorizia that had a fountain and many thick shady trees in a walled garden" (FTA 5). Gorizia was a city which belonged to the Austro-Hungarian Empire before the war. This house most likely belonged to a non Italian resident of the Austro-Hungarian Empire who left before the Italians had control of Gorizia. Many of the citizens were evacuated before the Italians arrived, so when they crossed the river into Gorizia, the Italian army was able to station themselves inside of houses that had been abandoned by civilians. Catherine stays in the house that serves as the British hospital, which Hemingway explains "had been the villa of a very wealthy German" (FTA 24). In "Now I Lay Me,"Nick is in a barn listening to silkworms chew. That barn belonged to someone. In "Nick Sat Against the Wall..." Nick leans against the wall of a church. That was a church where civilians would have 
gathered for worship, but now they are either evacuated, in hiding or dead in front of the church (143). In "A Way You'll Never Be," Nick has nightmares of a yellow house. Hemingway writes:

Outside of Fossalta there was a low house painted yellow with willows all around it and a low stable. There was a canal, and he had been here a thousand times and never seen it, but there it was every night as plain as the hill, only it frightened him. That house meant more than anything and every night he had it. (Hemingway 163)

The house appears in Nick's nightmares. In his waking moments Nick cannot find the house and the river is different, suggesting that the house was not real but only in his dreams. Nick would wake up "soaking wet, more frightened then he had ever been in a bombardment because of a house and a long stable and a canal" (The Nick Adams Stories 162). Later in the same story, Nick cannot sleep because of the image of the house (167). Nick is feeling guilt and concern for those who lived in the battlefield prior to the commencement of the war. The house should have been on the hill. A house and a barn belong on a canal more than dead soldiers do. Yet, the dead soldiers exist and the house does not. Nick regrets the loss of civilian lives and housing-and the loss is what means "more than anything." That house would have been Friuli, given its location just beyond the Piave. Nick is regretting the Friuli suffering, without mentioning the Friuli by name. Even if the specific house was not real, the idea of the missing and bombarded houses and lives is haunting Nick. In the yellow house readers are given a glimpse into the struggle Hemingway was having accepting the death and destruction he saw to the lives of the civilians in the war torn area of northeastern Italy and southwestern Slovenia.

The Slovene and Friuli presence is also felt in the rubble that forms the background setting on the front. Hemingway mentions passing by "a broken farmhouse" and "there were many iron shrapnel balls in the rubble of the houses and on the road beside the broken houses where the post was" (FTA 162). Lt Henry's post on the Bainsizza Plateau is situated near houses that have been blown up. At the start of the war this plateau was squarely within the Austro-Hungarian Empire. Lt Henry describes Gorizia upon his return to the front in what would have been the summer of 1916 (Reynolds), "The sudden interiors of houses that had lost a wall through shelling, with plaster and rubble in their gardens and sometimes in the street, and the whole thing going well on the Carso" (FTA 6). Here Hemingway juxtapositions a scene of the destruction of the homes of Slovene or Friuli with the victory the Italians are finding on the Carso, which is another Slovene plateau that belonged to the Austro-Hungarian Empire. Through this juxtaposition readers gain a glimpse of the victory the Italians are finding in 1916 at the cost of Slovenes and Friuli. 
There were Slovene and Fruili civilians who did not evacuate. According to Kranjc, "Able-bodied civilians were dragooned into labour units to dig defensive trenches and to transport goods to the front. Women, the young and the elderly were required to shoulder more of the agricultural labour and even children were employed gathering the "cotton' from the nettles for military uniforms" (214-15). These civilians worked for the military occupying their towns and they worked to farm their own land. Thus, when Italians came to Slovene and Friuli towns, they found food in the fields. In the start of FTA, Lt Henry notes that, "The plain was rich with crops; there were many orchards of fruit trees and beyond the plain the mountains...were brown and bare" (FTA 3). The mountains have been cleared for or by the battles, but in the plain the effects of the Slovenes and Friuli are still felt. Their crops are in the field. The fruits of their labors are left to be gleaned by Italian soldiers. Gino explains to Lt Henry, "When we came here [the Bainsizza] we found fields of potatoes the Austrians had planted" (FTA 160). The Bainsizza, however, was populated by Slovenes, not Austrians. Gino may not have known, but Slovenes would have planted the potatoes that he ate.

FTA is written retrospectively. Lt Henry is, just as Hemingway was, looking back and remembering the war. Lt Henry has had some time to think about who the Italians were fighting. Thus, Lt Henry declares "I did not know what we had against Austria" (FTA 65). He no longer knew why the Italians fought the Austrians, but did he know that the Slovenes were involved in the fight and that the fight was largely on their land? When Hemingway wrote about the weather in FTA, particularly in the Battle of Caporetto, he was careful to be accurate with the weather details from the actual nights he was writing about-even though he was not there to experience the weather himself. He researched thoroughly to insure accuracy. However, he does not accurately describe the army he is fighting, and he does not mention Slovenes by name. Lt. Henry states, "Croatians came over across the mountain meadows and through patches of woods and into the front line" (FTA 162) “...there were Croats in the lines opposite us now and some Magyars [Hungarians]" (FTA 159). He does not mention Slovenes being in the army. However, Slovenes were one of the Slavic nationalities serving in the Austro-Hungarian forces. According to Kranjc, "In the initial mobilization that followed the declaration of war in 1914, no less than 30,000 Slovene soldiers in Austrian uniform marched off to war...Tens of thousands of their comrades would follow their footsteps in the ensuing four years of war" (212). Many of these soldiers would initially be sent to the Eastern Front to fight against Russian and Serbian troops (Thompson 80). However, the Slavic troops were later moved to fight Italians. The Slovenes soon found themselves fighting Italy in their own country. Slovenes were fighting for land that was populated by Slovenes, giving them a better motivation for fighting the invading Italians. According to Slovene 
historian Dolenjska, Franc Rueh was a Slovene soldier moved back to fight in his homeland. In his journal Rueh wrote:

My heart seized for a moment when I saw those lands where I will perhaps spill my blood and lay down my life. However, when I gazed upon our beautiful Littoral, when I reached the sea, the tension released and my resolve hardened even more that I am prepared to sacrifice myself so that our enemies do not seize our beautiful lands (Kranjc 243).

Slovene soldiers were not necessarily in support of the empire, but they did want to defend their homeland. Thompson states that Slovenes were not aggressively anti Italian (144). However, while the Slovene citizens may not have fought actively against the Italians, the Slovene soldiers in the Austro Hungarian army defended their homeland against Italy, and they were there fighting the very army that Lt Henry was supporting. Not only were Slovenes in the Austro-Hungarian army, they were performing well in the army. According to Kranjc:

Slovene troops gained a reputation for professionalism and persistency in battle. During the war Slovenes fought within the ranks of units that were almost purely Slovene...the 17th and the 87th infantry regiments based in Ljubljana and Celje respectively, as well as the 2 nd mountain riffles regiment were almost entirely Slovene, while the 97 th infantry regiment based in Trieste was almost half Slovene. (212-213).

Thus, when Passini, Manera and Lt Henry are discussing the war and one of the men state, "What if we take the Carso and Monfalcone and Trieste," they were discussing fighting an army that was likely half Slovene (FTA 44). In this setting the soldiers speaking should have known they were fighting Slovenes just as they knew they were fighting Croatians and Magyars. The Slovenes are there, but they are not acknowledged by the Italian soldiers in the novel, just as Mussolini did not acknowledge the ethnicity of Stanko.

During the retreat from the Battle of Caporetto, Lt Henry and his men leave Gorizia in their ambulances. They are headed towards Udine, along with troops and civilians, but the retreating stalls and leads to a stop and go situation that continues into the night. The following morning, Aymo picks up two girls in the retreat (FTA 170). Aymo tells Henry, "I can't understand them" (FTA 170). The girls are not speaking Italian. Aymo tells the girls to "Tell the Tenente your name and what you're doing here" (170). The girls cannot understand Aymo and are terrified. They "looked fiercely" at Lt Henry (170). This line is followed by the girl saying "something in a dialect I could not understand a word of" (170). However, in the manuscript, Hemingway wrote the dialect "sounded like gibberish" and then crossed that line out (383). This is a dialect that is completely unfamiliar to the men and the girls do not understand them. This is a foreign dialect. Lt Henry asks the girls "Sorella?" which is Italian for sister, and the girls smile and nod. It is 
unclear if they fully understand the word or if Lt Henry's hand motions pointing to the two of them aided in understanding. The confusion continues as Aymo tries to explain to the girls that they will not be raped, that Aymo is a "good man" (170) and that there is no place for sex (171). The girls end up in tears, thinking that the men will rape them. In the end, Lt Henry asks if they are virgins, in Italian, and the girls seem cheered and "both girls nodded their heads and the elder said something in dialect" (171). Aymo responds that this is "all right" and the girls are cheered. They continue on the retreat with Lt Henry and his men until Lt Henry points down a road telling them to go, giving them money to aid in their retreat. These girls are important to the novel as they show the compassion of Lt Henry. They bring Catherine to his mind, as he seeks to protect them and wishes to protect Catherine, as well.

Branko Drekonja and Aleksander Potočnik explain that the scene with the sisters is "a scene of special interest for Slovene readers since it could represent the only contact between Hemingway's Lt Henry and local Slovene population" (201). They further state that Hemingway "mentions two girls that join Henry's crew during their retreat from Gorica [Gorizia]. They speak with a strange accent that neither Henry nor the other soldiers can understand. But he never pays any attention to their particular language, so we shall never know if they were speaking Slovene or Friulian" (20). That may be the case. This may be a mystery that will not be solved, but it is worth a reconsideration.

Perhaps the best way to consider the ethnicity of the sisters is to consider if historically they could have been Slovene. Slovenes were a prominent ethnicity along the Isonzo Front before the war began. In fact, many of the villages the Italians sought to "redeem" were villages populated entirely by Slovenes. According to Kranjc, "On the eve of the war, the Austrian authorities evacuated approximately 80,000 Slovene civilians from the vicinity of the Italian-Austrian border into the interior of the Empire, often to refugee camps...many of those who were not evacuated or chose to stay became displaced persons within Italy proper" (215). Thus, there were Slovenes who chose to stay within what became Italy during the war, choosing to stay in their homes rather than evacuate to a refugee camp. Drekonja and Potočnik tell of residents of the Slovene town of Kanal who chose to stay in Kanal for much of 1915, including Marija Bajt. The residents were eventually pushed out of the town, which would see fighting well into 1917 and is likely the location of Lt Henry's injury in 1917. In a town closer to Gorizia, it seems likely that Slovenes would stay as the fighting slowed in 1916 when Italians seized control and there was a reprieve from fighting under Italian occupation until the Battle of Caporetto in 1917. The town was safe enough that Lt Henry laughs off wearing his steel helmet in town and walks unafraid to the whore house and to the British hospital (FTA 24). Perhaps, then, if Slovenes were determined to 
stay in Kanal, a town under much military attack in 1915, they would have stayed in Gorizia, a town that Lt Henry lives in. According to Drekonja and Potočnik, Marija wrote in her diary at the time, "Italian soldiers tried to persuade us to go to Italy and save our lives. But despite the danger nobody felt like leaving his place of birth that day" (155). In August of 1915, when the town was finally needing to be evacuated fully, Marija retreated into Italy (Drekonja 109-10). There remains, then, the distinct possibility that Slovene sisters living in or near Gorizia during the Italian occupation would have fled further into Italy.

Mark Thompson states that Slovenes were the ethnic majority in much of the land fought over along the Isonzo Front. According to Thompson, the lands awarded to Italy under the Treaty of London were "home to some 230,000 Germanspeaking Austrians and up to 750,000 Slovenes and Croats, far outnumbering the 650,000 native Italians" (31). Areas such as the Carso and the Bainsizza plateau were populated almost entirely by Slovenes. While Caporetto and areas such as Bovec may have been eventually evacuated, they were not all evacuated from the start, just as the towns of Kanal and Gorizia. Slovenes may still have been in and around Gorizia in 1917. The city of Trieste held a majority of Italian civilians, overshadowing the Slovenes nearly 4/1 (Thompson 100). However, the areas around Trieste had an ethnicity of 51\% Slavic civilians. In these areas, Slovenes were used to living in Italian cities around Italian civilians. The idea of fleeing from Italians into a possible refugee camp in Austria may have seemed worse to many Slovene citizens. Thompson explains that the Italians saw no "cultural achievements" in the Slovenes and found that Slovenes communicated "in an incomprehensible tongue" (103). Over the course of the war, the Italians sought to force the Slovenes to "assimilate" through forced Italianzation (104). For this to happen, Slovenes must have remained in some of the towns along the front. In the cities of Trieste and Gorizia Thompson estimates half of the city evacuated $(133,145)$. Those Slovenes who chose to evacuate went further into "the interior of Italy" where they could not understand any of the Italian language and often led separate and submissive lives (140). In fact, life was better for Slovenes who chose to stay in Italy under occupation than for those who evacuated into Austria (Thompson 145). The Slovenes who stayed in Gorizia and the surrounding areas had become accustomed to the life they lived. They had adjusted. The Italian army had not abused them. A new army was coming through. Despite fighting for Austria, many Slovenes were leaning towards independence and an ethnic identity, instead of leaning towards either empire. Slovenes would have had a fear that the Austrian and German armies would not treat them as well as they had been treated in the previous occupation. There would have been a fear of becoming collateral damage. Thus there would have been Slovenes in the retreat from Gorizia, making it possible the girls in Aymo's car were Slovene or Friuli. The Germans 
had a reputation for fierceness along the front, so both ethnicities would have likely fled from them.

There is another set of young girls along the front towards the end of the war found in an unpublished manuscript. These two girls live in Roncade which "was a hot white town in the backwash of the June offensive" ("How Death Sought"). In a WWI report from the Red Cross, Major Guy Lowell writes, "The months of June and July [1918] were signalized by the great Austrian offensive and the successful Italian counteroffensive" ("WWI: Report" 5). Thus the Austrians had pushed past the Piave River, where the Italians had stopped after the retreat from Caporetto, and the Italians were able to push them back over the Piave and beyond. This put Roncade in the backwash of a June offensive that Hemingway himself would have experienced (Florczyk 67-8). Hemingway writes, "There was no one in Roncade except the town major and the two girls who ran the trattoria and cafe. Of course there were lots of other people...but all of them were going up toward the war or else coming back broken from the war" ("How Death Sought"). The two girls are alone in the town with one man who is not fighting in the war. In a second version of this short story, Hemingway reveals that the major, who is named Vergera, was "afraid to die." He is a man who is using his position of power to avoid the war. Vergera has "pudgy fingers" and is "fat" ("How Death Sought"). He sits behind the lines admiring a knife he got from an Arditi and looking at grenades. He is controlled by the "maggots of fear" in his mind. The two girls sleep "together in one bed" even though "there were plenty of beds in the Albergo [hotel] but they were frightened of the guns" ("How Death Sought"). All three are afraid, but the girls choose to sleep together for protection and comfort. They are sisters, and they find comfort in one another. These two girls are Aymo's virgins. The girls fled the area around Gorizia in the fall of 1917, following the Battle of Caporetto, and retreated along with the Italians. They found work in Roncade, perhaps through the lies they claim the town major has made to them. At the time of the retreat they did not speak Italian. The assumption must be made that the girls have learned Italian from October of 1917 to June of 1918, an achievable goal in a desperate situation. Their Italian would only need to be enough to converse with the Arditi briefly and to work in the trattoria.

One of the sisters is pregnant in Roncade, while both girls claim to be virgins in Gorizia. Here readers are given a look into Hemingway's portrayal of two innocent lives sucked up into a retreat and an offensive. Leaving Gorizia as virgins, they seek safety further in Italy. Once there, they meet the town major. The pregnant sister claims the town major is the father of her child, though he is an adult and she is sixteen. She claims to have "loved no one," and thus the idea is given that she did not have a choice in this sexual encounter. She fled Gorizia in fear of being raped. Lt Henry looked at her with compassion, and attempted to send her 
to safety. However, the safety he sends them to is false and their worst fear comes to fruition. Hemingway has shown a progression in disillusionment similar to the progression in FTA. The sisters' lives are worth nothing to the Italians in leadership and politics. What should have been safety for them is death and destruction.

As the story continues, an Arditi passes through the town and speaks with the girls. The Arditi discerns that the girls were not willing sexual partners with the town major. Hemingway once described the Arditi as "volunteers organized partly from criminals saving time for little mistakes like murder and assault" "The Woppian Way"). The description is fitting for the punishment the Arditi gives out. The Arditi goes up stairs to the major's bedroom, ties him up, and puts a grenade in his mouth. Thus, the Arditi, who is possibly a reformed criminal, saves the girls from the politician who is too afraid and fat to participate in a war he supports. Hemingway could not save the Slovene and Friuli civilians from the Italian government. Instead, the criminal soldier saved the Slovene girls from the rape of the Italian government.

The sisters could have been Friuli. However, Hemingway was familiar enough with Friulis that he was able to recognize what he felt were Friulian characteristics. In MF Hemingway described Gertrude Stein as having "beautiful eyes and a strong German-Jewish face that also could have been Friulano and she reminded me of a northern Italian peasant woman" (24). The manuscript for this portion exists in four versions - and each version uses "Friuliano" as a description for Stein. Hemingway was sure in this description. He was familiar with Friuli. Hemingway was familiar with several dialects in the area of northeastern Italy. In "Out of Season" he mentions a character speaking partially in "d'Ampezzo dialect and sometimes in Tyroler German dialect" (The Complete Short Stories 137). Hemingway took a trip to Italy in 1927 with Guy Hickock who recorded the both of them speaking with a priest "work[ing] hard at talking Italian instead of the San Marino dialect” (Trogdon 191). Hemingway was aware of Friuli and of dialects in northeastern Italy, but he does not show his familiarity with the Slovene language. Their language was "gibberish" in his writing. They were the "other" in his writing.

These sisters are Slovenes who, like Marija Bajt, fled the oncoming battle in Gorizia further into Italy where they could avoid being in a refugee camp. Just as the war is not mentioned in "Big Two Hearted River," yet the war is essential to the story, Slovenes are in the background, forming an important part of the story. They are the ripples in the story that lead to the "other" in Hemingway's works. As the "other" in Hemingway's works, they are present but not accounted for. 


\section{WORKS CITED}

Ammary, Silvia. The Influence of the European Culture on Hemingrway's Fiction. Lanham: Lexington Books, 2015. Print.

Baker, Carlos. Ernest Hemingway: A Life Story. New York: Scribner, 1969. Print. Baklan, Vid. Slovene Translator. March 22017

Drekonja, Branko and Aleksander Jankovič Potočnik. Hemingway's Trail of the Novel A Farewell to Arms. Bennington, VT: Merriam Press, 2013. Print.

Hemingway, Ernest. A Farewell to Arms HLE. New York: Scribner, 2012. Print

----. A Farewell to Arms. MS Box 07. John F. Kennedy Presidential Library. Boston, Mass

----. A Moveable Feast. MS Box 25, Folder 131 and MS 26. John F. Kennedy Presidential Library. Boston, Mass.

----. The Complete Short Stories of Ernest Hemingway, Finca Vigia ed. New York: Scribner, 2003. Print.

----. "How Death Sought out the Town Major of Roncade." MS Box 50, Folders, 477. John F. Kennedy Presidential Library. Boston, Mass.

----. The Nick Adams Stories. New York: Scribner, 2003. Print.

----. “The Woppian Way.” MS Box 62, Folder 843. John F. Kennedy Presidential Library. Boston, Mass

Kranjc, Gregor Joseph. "The Neglected War: The Memory of World War I in Slovenia." Journal of Slavic Military Studies-apr-june 2009 vol 22 issue 2 pp 208-235

Trogdon, Robert W. “I am Constructing a Legend': Ernest Hemingway in Guy Hickock's Brookyln Daily Eagle Articles. Resources for American Literary Study, vol 37. --2017 pp. 181-207.

"World War One: Program." Box OM22, World War One: ARC Folder 4. John F. Kennedy Presidential Library. Boston, Mass.

Rebecca Johnston

Santa Fe College, Gainesville rebecca.johnston@sfcollege.edu

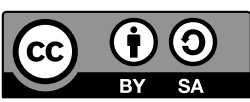




\section{Slovenci in Friuli kot tisti drugi pri Hemingwayju}

Ernest Hemingway je bil znan po svojem pisanju, ko je imel v mislih "teorije ledene gore". Tako v njegovih delih najdemo globlje pomene in kontekste, ki se gibljejo pod površino. Njegov vojni roman $A$ Farewell to Arms se odvija na soški fronti pred in po bitki pri Kobaridu v tem okolju, kar je v skladu z njegovo teorijo "ledene gore", saj je postavil oba protagonista $\mathrm{v}$ okolje, ki zahteva pogled pod površino. Medtem ko se Italijani na površini zgodbe and torej lažje prepoznavni, se Slovenci in Friuli tisti, ki so prisotni pod površino and imajo globlji pomen. Slovenci in Friuli neposredno niso omenjeni, toda ker je bil Hemingway zgodovinsko natančen $\mathrm{v}$ tem romanu, sta obe etnični skupini postavljeni na fronto in kolektivno predstavljata tistega "Drugega" v Hemnigwayjevih romanih, hkrati nevidnega in obenem kot pomemben del zgodbe.

Ključne beside: prva svetovna vojna, soška fronta, Hemingway, A Farewell to Arms, Slovenci, Friuli, italijanska fronta, Caporetto, Kobarid, Nick Adams 